\title{
School Disposal and Performance for Children of Different Birthweight Born 1953-1960
}

\author{
CECIL MARY DRILLIEN \\ From the Department of Child Life and Health, University of Edinburgh
}

A prospective study of the growth and development of singletons and twins of different birthweights, born in Edinburgh maternity hospitals, was begun in 1953. Details of sample selection, procedure, and findings in the first 9 years of the study are given elsewhere (Drillien, 1964).

The main sample of 596 infants was recruited in the years 1953-55. Because of the small proportion of infants weighing $1360 \mathrm{~g}$. or less, I continued to collect survivors in this very low birthweight group until 1960, giving a final sample of 648 infants distributed by birthweight as shown in Table I. Birthweight groups are now given in metric measures to conform with current practice. Approximately one-third of the final sample was $2000 \mathrm{~g}$. or less at birth, one-third 2001-2500 g., and one-third normal weight controls.

Distribution of the sample by sex and whether resulting from single or multiple pregnancy is given in Table II.

Table III gives losses from the sample over the years. The maximum losses occurred in the first 2 years of life. Of the original group born 1953-55 nearly $80 \%$ remained in the survey at $11-13$ years.

This paper describes the incidence of different handicapping conditions by birthweight, secondary school disposal following the transfer examination in primary school for those born 1953-55, and gives some information about primary school disposal and performance for those born 1955-60.

\section{Incidence of Handicap by Birthweight}

Table IV gives the incidence of handicap by birthweight at age 11-13 years (461 subjects) and 7 years (53 subjects). Children classified as having moderate or severe handicap included those who were ineducable in normal school on account of mental retardation, severe physical defect, or dull intelligence with disturbed behaviour; all those suffering from cerebral palsy and/or epilepsy, whether or not they were excluded from normal school, and one boy attending normal school who had congenital absence of the left arm. One boy in a special school for the hard of hearing has been omitted, as deafness was thought

TABLE I

Distribution of Survey Subjects by Birthweight

\begin{tabular}{|c|c|c|c|c|c|c|}
\hline \multirow{2}{*}{\multicolumn{3}{|c|}{ Birthweight (g.) }} & \multicolumn{2}{|c|}{ Date of Birth } & \multirow{2}{*}{ Total } & \multirow{2}{*}{$\%$} \\
\hline & & & $1953-55$ & $1955-60$ & & \\
\hline $\begin{array}{l}1500 \text { and under } \\
1501-2000 \\
2001-2500 \\
2501 \text { and over }\end{array}$ & $\begin{array}{l}\cdots \\
\cdots \\
\cdots\end{array}$ & $\begin{array}{l}\cdots \\
\cdots \\
\cdots \\
\cdots\end{array}$ & $\begin{array}{r}40 \\
110 \\
232 \\
214\end{array}$ & $\frac{52}{-}$ & $\begin{array}{r}92 \\
110 \\
232 \\
214\end{array}$ & $\begin{array}{l}14 \\
17 \\
36 \\
33\end{array}$ \\
\hline Total & . & $\ldots$ & 596 & 52 & 648 & 100 \\
\hline
\end{tabular}

TABLE II

Distribution by Sex and Single or Multiple Birth

\begin{tabular}{c|c|c|c|c|c}
\hline Sex & No. & $\%$ & Single/Multiple & No. & $\%$ \\
\hline Male & 310 & 48 & Single & 402 & 62 \\
Female & 338 & 52 & Multiple & 246 & 38 \\
\hline Total & 648 & 100 & Total & 648 & 100 \\
\hline
\end{tabular}

TABLE III

Losses from Sample by Age

\begin{tabular}{|c|c|c|c|c|}
\hline \multirow{2}{*}{\multicolumn{2}{|c|}{ No. in Sample at }} & \multicolumn{2}{|c|}{ Losses Due To: } & \multirow{2}{*}{$\begin{array}{c}\quad \% \\
\text { Survivors } \\
\text { Retained }\end{array}$} \\
\hline & & Death & Other Causes & \\
\hline $\begin{array}{l}\text { Birth } \\
2 \text { years } \\
5 \text { years } \\
7 \text { years } \\
\star 11-13 \text { years }\end{array}$ & $\begin{array}{l}648 \\
593 \\
571 \\
544 \\
462\end{array}$ & $\begin{array}{r}12 \\
2 \\
2\end{array}$ & $\begin{array}{l}43 \\
20 \\
27 \\
36\end{array}$ & $\begin{array}{l}93 \\
90 \\
86 \\
79\end{array}$ \\
\hline
\end{tabular}

^1953-55 births only 
TABLE IV

Degrees of Handicap by Birthweight

\begin{tabular}{|c|c|c|c|c|c|c|c|c|}
\hline \multirow{3}{*}{ Birthweight (g.) } & \multicolumn{6}{|c|}{ Degrees of Handicap } & \multirow{2}{*}{\multicolumn{2}{|c|}{ Total }} \\
\hline & \multicolumn{2}{|c|}{ Moderate/Severe } & \multicolumn{2}{|c|}{ Some } & \multicolumn{2}{|c|}{ Little/None } & & \\
\hline & No. & $\%$ & No. & $\%$ & No. & $\%$ & No. & $\%$ \\
\hline $\begin{array}{l}1250 \text { and under } \\
1251-1500 \\
1501-1750 \\
1751-2000 \\
2001-2250 \\
2251-2500 \\
2501 \text { and over }\end{array}$ & $\begin{array}{r}23 \\
16 \\
5 \\
8 \\
2 \\
3 \\
2\end{array}$ & $\begin{array}{r}64 \\
34 \\
19 \\
12 \\
4 \\
3 \\
1\end{array}$ & $\begin{array}{r}6 \\
10 \\
6 \\
20 \\
13 \\
19 \\
20\end{array}$ & $\begin{array}{l}17 \\
21 \\
23 \\
30 \\
23 \\
16 \\
12\end{array}$ & $\begin{array}{r}7 \\
21 \\
15 \\
39 \\
42 \\
94 \\
143\end{array}$ & $\begin{array}{l}19 \\
45 \\
58 \\
58 \\
74 \\
81 \\
87\end{array}$ & $\begin{array}{r}36 \\
47 \\
26 \\
67 \\
57 \\
116 \\
165\end{array}$ & $\begin{array}{l}100 \\
100 \\
100 \\
100 \\
100 \\
100 \\
100\end{array}$ \\
\hline
\end{tabular}

to be due to meningococcal meningitis, and not associated with low birthweight.

Children classified as having some handicap were all educable in normal school, but the majority had educational difficulties associated with dull intelligence (IQ levels 70-79) and/or marked behaviour problems at 11 years. Children with disturbed behaviour who had not reached the age of 11 were not included, as this type of behaviour in low weight children tends to improve after the age of 7 . Five children classified as having some handicap had physical defects only, which did not affect school performance but did constitute a definite disability, such as cleft palate and high myopia. Children classified as having little or no handicap were those suffering from none of the conditions mentioned. As would be expected, the incidence of moderate or severe handicap increased, and the proportion of children classified as having little or no handicap decreased with decreasing birthweight. The incidence of moderate or severe handicap was not much increased at birthweights of 2001-2500 g.

Incidence of handicap by sex. Table V gives incidence of handicap by birthweight and sex. The incidence of moderate or severe handicap in males of $1500 \mathrm{~g}$. and under was one and a half times that of females, and nearly three times that of females in the birthweight group 1501-2000 g. This appeared to be due to the vulnerability of male infants to adverse prenatal effects of severe maternal complications in late pregnancy, especially toxaemia and chronic cardiac and renal diseases. At and below birthweights of $2000 \mathrm{~g}$. the proportion of low weight births associated with severe pregnancy complications increased with increasing birthweight.

Incidence of handicap by single or multiple birth. Table VI gives the incidence of handicap by birthweight and whether the infant resulted from a single or multiple birth. At birthweights of $2000 \mathrm{~g}$. or less singletons appeared to be at a slightly increased risk of moderate or severe handicap. Less serious problems were more common in children resulting from multiple pregnancies in most birthweight groups, thus the proportion of children considered to have little or no handicap was generally lower for those resulting from multiple pregnancies.

TABLE V

Degrees of Handicap by Birthweight and Sex

\begin{tabular}{|c|c|c|c|c|c|c|c|c|c|c|c|c|c|c|c|c|}
\hline \multirow{3}{*}{ Birthweight (g.) } & \multicolumn{8}{|c|}{ Male } & \multicolumn{8}{|c|}{ Female } \\
\hline & \multicolumn{2}{|c|}{$\begin{array}{c}\text { Moderate/ } \\
\text { Severe }\end{array}$} & \multicolumn{2}{|c|}{ Some } & \multicolumn{2}{|c|}{ None } & \multicolumn{2}{|c|}{ Total } & \multicolumn{2}{|c|}{$\begin{array}{c}\text { Moderate/ } \\
\text { Severe }\end{array}$} & \multicolumn{2}{|c|}{ Some } & \multicolumn{2}{|c|}{ None } & \multicolumn{2}{|c|}{ Total } \\
\hline & No. & $\%$ & No. & $\%$ & No. & $\%$ & No. & $\%$ & No. & $\%$ & No. & $\%$ & No. & $\%$ & No. & $\%$ \\
\hline $\begin{array}{l}-1500 \\
1501-2000 \\
2001-2500 \\
2501-\end{array}$ & $\begin{array}{r}21 \\
10 \\
2 \\
1\end{array}$ & $\begin{array}{r}60 \\
20 \\
2 \\
1\end{array}$ & $\begin{array}{r}6 \\
16 \\
21 \\
13\end{array}$ & $\begin{array}{l}17 \\
33 \\
26 \\
16\end{array}$ & $\begin{array}{r}8 \\
23 \\
59 \\
67\end{array}$ & $\begin{array}{l}23 \\
47 \\
72 \\
83\end{array}$ & $\begin{array}{l}35 \\
49 \\
82 \\
81\end{array}$ & $\begin{array}{l}100 \\
100 \\
100 \\
100\end{array}$ & $\begin{array}{r}18 \\
3 \\
3 \\
1\end{array}$ & $\begin{array}{r}38 \\
7 \\
3 \\
1\end{array}$ & $\begin{array}{r}10 \\
10 \\
11 \\
7\end{array}$ & $\begin{array}{r}21 \\
23 \\
12 \\
8\end{array}$ & $\begin{array}{l}20 \\
31 \\
77 \\
76\end{array}$ & $\begin{array}{l}42 \\
71 \\
85 \\
91\end{array}$ & $\begin{array}{l}48 \\
44 \\
91 \\
84\end{array}$ & $\begin{array}{l}100 \\
100 \\
100 \\
100\end{array}$ \\
\hline
\end{tabular}


TABLE VI

Degrees of Handicap by Birthweight and Single or Multiple Birth

\begin{tabular}{|c|c|c|c|c|c|c|c|c|c|c|c|c|c|c|c|c|}
\hline \multirow{3}{*}{$\begin{array}{l}\text { Birthweight } \\
\text { (g.) }\end{array}$} & \multicolumn{8}{|c|}{ Single Birth } & \multicolumn{8}{|c|}{ Multiple Birth } \\
\hline & \multicolumn{2}{|c|}{ Moderate/Severe } & \multicolumn{2}{|c|}{ Some } & \multicolumn{2}{|c|}{ None } & \multicolumn{2}{|c|}{ Total } & \multicolumn{2}{|c|}{ Moderate/Severe } & \multicolumn{2}{|c|}{ Some } & \multicolumn{2}{|c|}{ None } & \multicolumn{2}{|c|}{ Total } \\
\hline & No. & $\%$ & No. & $\%$ & No. & $\%$ & No. & $\%$ & No. & $\%$ & No. & $\%$ & No. & $\%$ & No. & $\%$ \\
\hline $\begin{array}{l}-1500 \\
1501-2000 \\
2001-2500 \\
2501-\end{array}$ & $\begin{array}{r}29 \\
8 \\
5 \\
1\end{array}$ & $\begin{array}{r}49 \\
15 \\
4 \\
1\end{array}$ & $\begin{array}{r}9 \\
15 \\
20 \\
11\end{array}$ & $\begin{array}{l}15 \\
28 \\
16 \\
11\end{array}$ & $\begin{array}{r}21 \\
31 \\
100 \\
85\end{array}$ & $\begin{array}{l}36 \\
57 \\
80 \\
88\end{array}$ & $\begin{array}{r}59 \\
54 \\
125 \\
97\end{array}$ & $\begin{array}{l}100 \\
100 \\
100 \\
100\end{array}$ & $\begin{array}{r}10 \\
5 \\
-1\end{array}$ & $\begin{array}{l}42 \\
\frac{13}{2}\end{array}$ & $\begin{array}{r}7 \\
11 \\
12 \\
9\end{array}$ & $\begin{array}{l}29 \\
28 \\
25 \\
13\end{array}$ & $\begin{array}{r}7 \\
23 \\
36 \\
58\end{array}$ & $\begin{array}{l}29 \\
59 \\
75 \\
85\end{array}$ & $\begin{array}{l}24 \\
39 \\
48 \\
68\end{array}$ & $\begin{array}{l}100 \\
100 \\
100 \\
100\end{array}$ \\
\hline
\end{tabular}

TABLE VII

Secondary School Disposal by Birthweight, Sex, andSocial Grade

\begin{tabular}{|c|c|c|c|c|c|c|c|c|c|c|c|c|c|c|}
\hline \multirow{4}{*}{ Social Grade } & \multirow{4}{*}{\multicolumn{2}{|c|}{ Secondary School }} & \multicolumn{12}{|c|}{ Birthweight (g.) } \\
\hline & & & \multicolumn{4}{|c|}{-2000} & \multicolumn{4}{|c|}{$2001-2500$} & \multicolumn{4}{|c|}{$2501-$} \\
\hline & & & \multirow{2}{*}{$\frac{\text { M }}{\text { No. }}$} & \multirow{2}{*}{$\frac{F}{\text { No. }}$} & \multicolumn{2}{|c|}{ Total } & \multirow{2}{*}{$\frac{\mathrm{M}}{\text { No. }}$} & \multirow{2}{*}{$\frac{F}{\text { No. }}$} & \multicolumn{2}{|c|}{ Total } & \multirow{2}{*}{$\frac{M}{\text { No. }}$} & \multirow{2}{*}{$\frac{\mathrm{F}}{\text { No. }}$} & \multicolumn{2}{|c|}{ Total } \\
\hline & & & & & No. & $\%$ & & & No. & $\%$ & & & No. & $\%$ \\
\hline \multirow[t]{2}{*}{1 and 2} & $\begin{array}{l}\text { Ineducable Normal School } \\
\text { Modified Secondary } \\
\text { Junior Secondary } \\
\text { Senior Secondary } 4 \text { yr. } \\
\text { Senior Secondary 5-6 yr. }\end{array}$ & & $\begin{array}{r}3 \\
1 \\
13 \\
2 \\
4\end{array}$ & $\begin{array}{r}1 \\
3 \\
14 \\
4 \\
9\end{array}$ & $\begin{array}{r}4 \\
4 \\
27 \\
6 \\
13\end{array}$ & $\begin{array}{r}7 \\
7 \\
50 \\
11 \\
24\end{array}$ & $\begin{array}{r}-1 \\
13 \\
6 \\
9\end{array}$ & $\begin{array}{r}- \\
12 \\
9 \\
14\end{array}$ & $\begin{array}{r}-1 \\
25 \\
15 \\
23\end{array}$ & $\begin{array}{r}- \\
2 \\
39 \\
23 \\
36\end{array}$ & $\begin{array}{l}\overline{10} \\
14 \\
20\end{array}$ & $\begin{array}{l}- \\
- \\
11 \\
18\end{array}$ & $\begin{array}{l}- \\
20 \\
25 \\
38\end{array}$ & $\begin{array}{l}- \\
- \\
30 \\
46\end{array}$ \\
\hline & Total $\quad \ldots$ & $\cdots$ & 23 & 31 & 54 & 100 & 29 & 35 & 64 & 100 & 44 & 39 & 83 & 100 \\
\hline \multirow[t]{2}{*}{3} & $\begin{array}{l}\text { Ineducable Normal School } \\
\text { Modified Secondary .. } \\
\text { Junior Secondary } \ldots \\
\text { Senior Secondary } 4 \text { yr. } \\
\text { Senior Secondary 5-6 yr. }\end{array}$ & $\begin{array}{l}\cdots \\
\cdots \\
\cdots \\
\cdots \\
\cdots\end{array}$ & $\begin{array}{r}8 \\
5 \\
10 \\
1 \\
-\end{array}$ & $\begin{array}{l}1 \\
4 \\
9 \\
1 \\
4\end{array}$ & $\begin{array}{r}9 \\
9 \\
19 \\
2 \\
4\end{array}$ & $\begin{array}{r}21 \\
21 \\
44 \\
5 \\
9\end{array}$ & $\begin{array}{r}- \\
4 \\
20 \\
10 \\
4\end{array}$ & $\begin{array}{r}- \\
1 \\
28 \\
6 \\
3\end{array}$ & $\begin{array}{r}- \\
5 \\
48 \\
16 \\
7\end{array}$ & $\begin{array}{r}-7 \\
63 \\
21 \\
9\end{array}$ & $\begin{array}{r}1 \\
17 \\
5 \\
2\end{array}$ & $\begin{array}{r}- \\
2 \\
18 \\
8 \\
2\end{array}$ & $\begin{array}{r}1 \\
2 \\
35 \\
13 \\
4\end{array}$ & $\begin{array}{r}2 \\
4 \\
64 \\
24 \\
7\end{array}$ \\
\hline & Total $\quad \ldots \quad \ldots$ & $\cdots$ & 24 & 19 & 43 & 100 & 38 & 38 & 76 & 100 & 25 & 30 & 55 & 100 \\
\hline \multirow[t]{2}{*}{4} & $\begin{array}{l}\text { Ineducable Normal School } \\
\text { Modified Secondary .. } \\
\text { Junior Secondary } \ldots \\
\text { Senior Secondary } 4 \text { yr. } \\
\text { Senior Secondary 5-6 yr. }\end{array}$ & $\begin{array}{l}\cdots \\
\cdots \\
\cdots \\
\cdots \\
\cdots\end{array}$ & $\begin{array}{r}6 \\
5 \\
7 \\
- \\
\end{array}$ & $\begin{array}{r}2 \\
4 \\
4 \\
1 \\
-\end{array}$ & $\begin{array}{r}8 \\
9 \\
11 \\
1 \\
-\end{array}$ & $\begin{array}{r}28 \\
31 \\
38 \\
3 \\
-\end{array}$ & $\begin{array}{r}1 \\
11 \\
2 \\
-\end{array}$ & $\begin{array}{r}1 \\
6 \\
10 \\
1 \\
-\end{array}$ & $\begin{array}{r}2 \\
17 \\
12 \\
1 \\
\end{array}$ & $\begin{array}{r}6 \\
53 \\
38 \\
3 \\
-\end{array}$ & $\begin{array}{r}-4 \\
7 \\
1 \\
\end{array}$ & $\begin{array}{r}- \\
4 \\
6 \\
3 \\
1\end{array}$ & $\begin{array}{r}-8 \\
13 \\
4 \\
1\end{array}$ & $\begin{array}{r}- \\
31 \\
50 \\
15 \\
4\end{array}$ \\
\hline & Total & . & 18 & 11 & 29 & 100 & 14 & 18 & 32 & 100 & 12 & 14 & 26 & 100 \\
\hline
\end{tabular}

\section{Secondary School Disposal}

Of the 462 children born 1953-55 and retained in the survey, 24 were ineducable in normal school, 22 attended private schools in Edinburgh, and 416 attended local authority primary schools, two-thirds in Edinburgh and one-third in other counties of Scotland.

Though Scottish education is now moving towards a comprehensive system, the type of initial secondary school course for children in this group was decided on the old methods of selection, i.e. on the results of group IQ tests carried out in the past two years of primary school; on educational tests in English and Arithmetic in the last year, and on head teachers' reports and recommendations. The most backward children in the primary schools, with IQ levels in the range 70-79, were considered unsuitable for the normal secondary school course and followed a modified course; others were selected for a 3-year junior secondary school course, for a 4-year course in senior secondary school, or for a 5-6-year course. The secondary school course selected was known for 14 children attending private schools whose pupils do not take the transfer examination.

Table VII gives the initial course selected at age 11-13 years by birthweight, sex, and social grade. Of children who had been over $2500 \mathrm{~g}$. 
at birth and reared in middle class and superior working class homes (Social Grades 1 and 2), $76 \%$ were selected for senior secondary school courses as compared with $59 \%$ of those of birthweight $2001-2500 \mathrm{~g}$. and $35 \%$ of those who were 2000 g. or less. Of children reared in average working class homes (Social Grade 3), there was little difference in school disposal between those who were $2001-2500 \mathrm{~g}$. and those who were above this weight at birth, but there was a marked increase in children who were ineducable in normal school or considered capable only of following a modified course in those who were $2000 \mathrm{~g}$. or less at birth (42\%) compared with children who were over $2000 \mathrm{~g}$. at birth $(6 \%)$. Of children reared in the poorest homes (Social Grade 4) and of birthweight over 2500 g., all were educable in normal school, $31 \%$ followed a modified course, $50 \%$ the normal junior secondary course, and $19 \%$ entered senior secondary schools. When birthweight was 2001$2500 \mathrm{~g}$. there was a marked increase in the proportion of children capable only of a modified course $(53 \%)$, and among those of $2000 \mathrm{~g}$. or less a marked increase in those who were ineducable in normal school (28\%), though the proportion selected for normal junior and secondary school courses was similar for children of $2000 \mathrm{~g}$. and under as it was for those of 2001-2500 g.

\section{Group Intelligence Test Results}

All children attending local authority primary schools and 8 children attending private schools took a verbal reasoning test in primary class VI and again in class VII. Table VIII gives the mean scores on these two tests for children of different birthweights from different types of home; the difference in mean IQ by birthweight for children reared in similar types of home and the difference in mean IQ for children of similar birthweight reared in different types of home.

Mean IQ scores fell with decreasing birthweight in all social groups, and in all birthweight groups IQ score fell with declining social status. Differences observed between children of like birthweight at opposite ends of the social scale were greater than the differences between those lightest and heaviest at birth from similar types of home.

Though the incidence of moderate or severe handicaps was not much increased in children of birthweight 2001-2500 g., they were found to be at some disadvantage in normal school.

The differences shown in Table VIII are minimal since children from the poorest homes were most likely to be considered ineducable in normal school; these did not sit the transfer examination. In addition, a number of children from the best homes attended private schools where these tests were not taken. Table IX includes the last known intelligence test results for 24 children attending special schools and the results on the Terman and Merrill L-form Test at age 5-7 years for 23 children attending private schools ( 9 of these were only followed to 7 years and are not included in other analyses). Bigger differences in mean IQ scores by birthweight and social grade are now evident.

When considering the intellectual status of a child who was of low birthweight, it is important to pay regard to the normal expectations of his particular family. In Table X IQ scores of children of birthweight $2501 \mathrm{~g}$. and over were arranged in ascending order, and the centile ranking is given in the first column of the Table by social grade. Thus, of children reared in the best homes, onehalf scored between 102 and 120, one-quarter 121 and over, and one-quarter 101 and under. Similarly, of children reared in the worst homes, onehalf scored between 79 and 100, one-quarter 101 and over, and one-quarter 78 and under. One might consider that children scoring below the 25th centile in each social group were not fulfilling the expectations of their families.

TABLE VIII

Mean IQ Scores at 11-13 years by Birthweight and Social Grade

\begin{tabular}{|c|c|c|c|c|c|c|c|}
\hline \multirow{3}{*}{ Social Grade } & \multicolumn{7}{|c|}{ Birthweight (g.) } \\
\hline & & $\begin{array}{c}A \\
-2000\end{array}$ & \multicolumn{2}{|c|}{$2001-2500$} & \multicolumn{2}{|r|}{$\begin{array}{c}\text { B } \\
2501-\end{array}$} & \multirow{2}{*}{$\frac{\mathrm{B}-\mathrm{A}}{\text { Mean IQ }}$} \\
\hline & No. & Mean IQ & No. & Mean IQ & No. & Mean IQ & \\
\hline $\begin{array}{c}1 \text { and } 2 \\
3 \\
4\end{array}$ & $\begin{array}{l}43 \\
35 \\
21\end{array}$ & $\begin{array}{r}100 \cdot 0 \\
90 \cdot 7 \\
83 \cdot 7\end{array}$ & $\begin{array}{l}61 \\
78 \\
29\end{array}$ & $\begin{array}{r}105 \cdot 7 \\
97 \cdot 6 \\
82 \cdot 6\end{array}$ & $\begin{array}{l}76 \\
54 \\
27\end{array}$ & $\begin{array}{r}109 \cdot 9 \\
100 \cdot 4 \\
90 \cdot 9\end{array}$ & $\begin{array}{l}+9.9 \\
+9.7 \\
+7.2\end{array}$ \\
\hline SG 1 and 2 to SG 4 & & $+16 \cdot 3$ & & $+23 \cdot 1$ & & $+19 \cdot 0$ & \\
\hline
\end{tabular}


TABLE IX

Mean IQ Scores at Transfer Examination (424 subjects) and at 7-10 years (47 subjects)

\begin{tabular}{|c|c|c|c|c|c|c|c|}
\hline \multirow{3}{*}{ Social Grade } & \multicolumn{7}{|c|}{ Birthweight (g.) } \\
\hline & & $\underset{-2000}{A}$ & \multicolumn{2}{|c|}{$2001-2500$} & \multicolumn{2}{|r|}{$\underset{2501-}{\text { B }}$} & \multirow{2}{*}{$\frac{\text { B-A }}{\text { Mean IQ }}$} \\
\hline & No. & Mean IQ & No. & Mean IQ & No. & Mean IQ & \\
\hline $\begin{array}{c}1 \text { and } 2 \\
3 \\
4\end{array}$ & $\begin{array}{l}53 \\
45 \\
29\end{array}$ & $\begin{array}{r}100 \cdot 3 \\
85 \cdot 2 \\
76 \cdot 1\end{array}$ & $\begin{array}{l}66 \\
79 \\
31\end{array}$ & $\begin{array}{r}106 \cdot 2 \\
97 \cdot 4 \\
80 \cdot 8\end{array}$ & $\begin{array}{l}86 \\
55 \\
27\end{array}$ & $\begin{array}{r}111 \cdot 9 \\
99 \cdot 4 \\
90 \cdot 9\end{array}$ & $\begin{array}{l}+11 \cdot 6 \\
+14 \cdot 2 \\
+14 \cdot 8\end{array}$ \\
\hline SG 1 and 2 to SG 4 & & $+24 \cdot 2$ & & $25 \cdot 4$ & & $+21 \cdot 0$ & \\
\hline
\end{tabular}

Columns 2 and 3 give the proportion of children of birthweight 2001-2500 g. and $2000 \mathrm{~g}$. and under respectively, whose IQ scores fell below the 25 th centile, at the 25 th but less than the 75th centile, and at the 75th centile or above, for normal weight children from similar types of home.

It will be seen that in all social grades the proportion falling below the 25 th centile for mature controls increased and the proportion scoring at or above the 75 th centile decreased with decreasing birthweight.

Though it is generally agreed that children who were of low birthweight have a higher than average incidence of severe physical, mental, and neurological defects, it has been claimed that once these more severely handicapped children are excluded, low birthweight has little influence on later status. Table XI gives mean IQ scores of survey children in two low birthweight groups and of control children after the exclusion of all with moderate or severe handicaps; thus, all children with IQ levels of less than 70 are excluded, as are some with IQs between 70 and 79 who proved ineducable in normal school, and all with neurological defects.

Of the 44 children of birthweight $1500 \mathrm{~g}$. or less, 20 were born 1953-55 and the IQ scores were those obtained at the transfer examination; 24 children were born 1955-60 and the IQ scores were obtained on individual testing at 5-7 years. Mean IQ of children born 1955-60 was higher than that obtained on results of group testing. IQ scores of children over $1500 \mathrm{~g}$. at birth were obtained at the transfer examination.

Even after exclusion of all children with moderate or severe mental, neurological, or physical defects,

TABLE X

IQ Score by Centile Ranking for Normal Weight Controls and Low Weight Children from Similar Homes

\begin{tabular}{|c|c|c|c|c|c|c|}
\hline \multirow{3}{*}{ Social Grade } & \multicolumn{6}{|c|}{ Birthweight (g.) } \\
\hline & \multicolumn{2}{|c|}{2501 and over } & \multicolumn{2}{|c|}{$2001-2500$} & \multicolumn{2}{|c|}{2000 and under } \\
\hline & IQ Centile & Score & No. & $\%$ & No. & $\%$ \\
\hline \multirow[t]{2}{*}{1 and 2} & $\begin{array}{l}<25 \text { th } \\
25 \text { th }-<75 \text { th } \\
75 \text { th and over }\end{array}$ & $\begin{array}{c}<102 \\
102-120 \\
121 \text { and over }\end{array}$ & $\begin{array}{l}26 \\
29 \\
11\end{array}$ & $\begin{array}{l}39 \\
44 \\
17\end{array}$ & $\begin{array}{r}29 \\
19 \\
5\end{array}$ & $\begin{array}{r}55 \\
36 \\
9\end{array}$ \\
\hline & Total & & 66 & 100 & 53 & 100 \\
\hline \multirow[t]{2}{*}{3} & $\begin{array}{l}<25 \text { th } \\
25 \text { th }-<75 \text { th } \\
75 \text { th and over }\end{array}$ & $\begin{array}{c}<92 \\
92-110 \\
111 \text { and over }\end{array}$ & $\begin{array}{l}28 \\
37 \\
14\end{array}$ & $\begin{array}{l}36 \\
47 \\
18\end{array}$ & $\begin{array}{r}29 \\
11 \\
5\end{array}$ & $\begin{array}{l}64 \\
25 \\
11\end{array}$ \\
\hline & Total & & 79 & 100 & 45 & 100 \\
\hline \multirow[t]{2}{*}{4} & $\begin{array}{l}<25 \text { th } \\
25 \text { th }-<75 \text { th } \\
75 \text { th and over }\end{array}$ & $\begin{array}{c}<79 \\
79-100 \\
101 \text { and over }\end{array}$ & $\begin{array}{r}15 \\
14 \\
2\end{array}$ & $\begin{array}{r}48 \\
45 \\
6\end{array}$ & $\begin{array}{r}14 \\
12 \\
1\end{array}$ & $\begin{array}{r}52 \\
44 \\
4\end{array}$ \\
\hline & Total & & 31 & 100 & 27 & 100 \\
\hline
\end{tabular}


TABLE XI

IQ Score by Birthweight and Social Grade after Excluding all with Moderate or Severe Handicaps

\begin{tabular}{|c|c|c|c|c|c|c|c|}
\hline \multirow{3}{*}{ Social Grade } & \multicolumn{6}{|c|}{ Birthweight (g.) } & \multirow{3}{*}{$\mathbf{B}-\mathbf{A}$} \\
\hline & \multicolumn{2}{|c|}{$\begin{array}{c}\text { A } \\
-1500\end{array}$} & \multicolumn{2}{|c|}{$1501-2000$} & \multicolumn{2}{|c|}{$\begin{array}{c}\text { B } \\
2501-\end{array}$} & \\
\hline & No. & Score & No. & Score & No. & Score & \\
\hline $\begin{array}{c}1 \text { and } 2 \\
3 \\
4\end{array}$ & $\begin{array}{l}19 \\
12 \\
13\end{array}$ & $\begin{array}{l}93 \cdot 5 \\
88 \cdot 2 \\
84 \cdot 2\end{array}$ & $\begin{array}{l}30 \\
27 \\
14\end{array}$ & $\begin{array}{r}101 \cdot 5 \\
94 \cdot 9 \\
84 \cdot 4\end{array}$ & $\begin{array}{l}75 \\
53 \\
26\end{array}$ & $\begin{array}{r}110 \cdot 5 \\
100 \cdot 1 \\
90 \cdot 4\end{array}$ & $\begin{array}{r}17 \cdot 0 \\
11 \cdot 9 \\
6 \cdot 2\end{array}$ \\
\hline SG 1 and 2 to SG 4 & \multicolumn{2}{|c|}{$9 \cdot 3$} & \multicolumn{2}{|c|}{$17 \cdot 1$} & \multicolumn{2}{|c|}{$20 \cdot 1$} & \\
\hline Total & 44 & & 71 & & 154 & & \\
\hline
\end{tabular}

TABLE XII

Transfer Examination Scores at 11-13 years by Birthweight and Sex, Standardized for Social Grade

\begin{tabular}{|c|c|c|c|c|c|c|}
\hline \multirow{2}{*}{ Birthweight (g.) } & \multirow{2}{*}{$\begin{array}{l}\text { Mean } \\
\text { Score }\end{array}$} & \multicolumn{2}{|c|}{ Female } & \multicolumn{2}{|c|}{ Male } & \multirow{2}{*}{$\mathrm{F}-\mathrm{M}$} \\
\hline & & No. & Score & No. & Score & \\
\hline A: 2000 and under & $\begin{array}{l}\text { IQ } \\
\text { English } \\
\text { Arithmetic }\end{array}$ & 41 & $\begin{array}{l}97 \cdot 3 \\
51 \cdot 9 \\
51 \cdot 1\end{array}$ & 34 & $\begin{array}{l}91 \cdot 0 \\
43 \cdot 3 \\
43 \cdot 5\end{array}$ & $\begin{array}{l}+6 \cdot 3 \\
+8 \cdot 6 \\
+7 \cdot 6\end{array}$ \\
\hline B : 2501 and over & $\begin{array}{l}\text { IQ } \\
\text { English } \\
\text { Arithmetic }\end{array}$ & 77 & $\begin{array}{r}102 \cdot 4 \\
58 \cdot 8 \\
57 \cdot 2\end{array}$ & 63 & $\begin{array}{r}103 \cdot 6 \\
54 \cdot 9 \\
56 \cdot 6\end{array}$ & $\begin{array}{l}-1 \cdot 2 \\
+3 \cdot 9 \\
+0.6\end{array}$ \\
\hline B-A & $\begin{array}{l}\text { IQ } \\
\text { English } \\
\text { Arithmetic }\end{array}$ & & $\begin{array}{l}+5 \cdot 1 \\
+6 \cdot 9 \\
+6 \cdot 1\end{array}$ & & $\begin{array}{l}+12 \cdot 6 \\
+11 \cdot 6 \\
+13 \cdot 1\end{array}$ & \\
\hline
\end{tabular}

there was still a difference in IQ score by birthweight in children brought up in all types of home, in spite of the slight advantage given to those of $1500 \mathrm{~g}$. or less by using individual test score results. The difference was least marked in those reared in the poorest homes. This point will be referred to in a later section.

\section{Influence of Sex on School Performance}

It has been shown in a previous section that moderate or severe handicap was much increased in boys who were $2000 \mathrm{~g}$. or less at birth as compared with girls. Even after excluding children with these handicaps, low weight girls were still found to be at an advantage as compared with low weight boys, as is shown in Table XII. This Table gives mean IQ scores at the secondary school transfer examination, and also mean scores on educational tests in English and Arithmetic for girls and boys who weighed $2000 \mathrm{~g}$. or less at birth and normal birthweight control children, after standardizing for differences in social grade distribution by birthweight. These figures refer to children receiving their education in Edinburgh local authority primary schools and children in a few other schools who used the same educational tests in English and Arithmetic. Mean IQ of normal birthweight controls was little different for boys and girls; in educational attainment there was also not much difference, though girls scored higher as might be expected from their earlier age of puberty (Tanner, 1962). However, among those who were of low birthweight, there was a quite obvious difference by sex both in mean IQ score and performance in school subjects.

The bottom section shows the comparison in score between those who were of low birthweight and normal weight controls, and shows that though in all respects the normal weight children scored higher, differences by birthweight were much more marked for boys.

\section{Mental Testing at Different Ages}

In the preschool period, developmental testing on Gesell type tests, was attempted at 6,12 , and 18 months and 2, 3, and 4 years. Individual 
intelligence tests using the Terman and Merrill revision of the Stanford Binet Scale (L or L-M tests) were applied at ages 5 to 7 years.

An examination was made of the response to mental testing at different ages, of children of different birthweights, reared in different types of home. This is illustrated in the Fig. Of the 596 survey children born $1953-55,173$ were lost to the survey before the transfer examination or were retained in the survey but attended schools where this examination was not taken. 58 children were

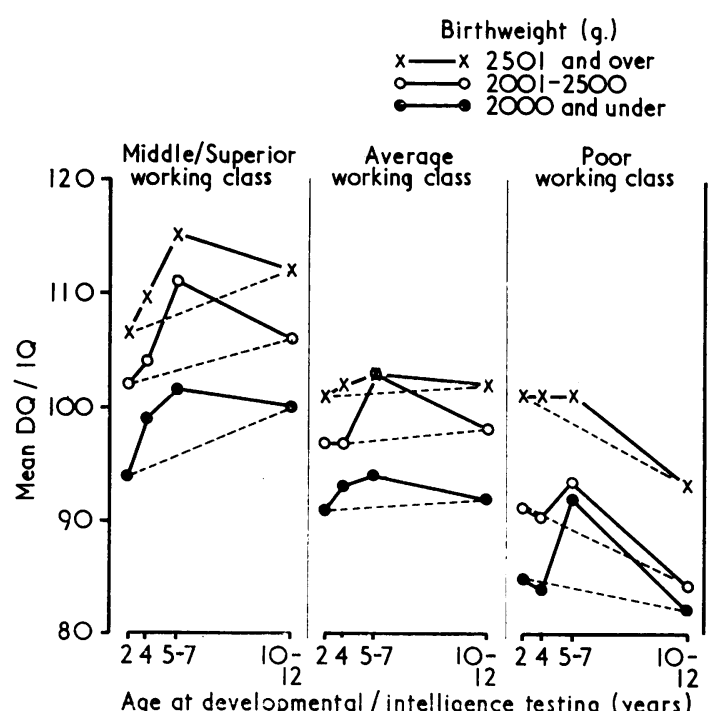

FIG.-Mean scores on developmental and intelligence testing at ages 2 to 10-12 years, by birthweight and social grade.

not adequately tested at all ages in the preschool period, and in 365 cases $(61 \%)$ an adequate test result was obtained on at least 3 of 4 examinations in the first 2 years, and at one or both of the 3- and 4-year examinations. All were given the TermanMerrill test at 5-7 years and Verbal Reasoning group tests at the transfer examination.

It is likely that different abilities were being tested at different ages and that results on different types of tests are not strictly comparable. In particular, in all social groups the mean IQ as determined by the Terman-Merrill test at 5-7 years was higher both than that obtained on developmental testing in the preschool period and that obtained on group IQ tests in school at the transfer examination. However, as all the children received the same test at the same age, trends, which are indicated by the broken lines, can be compared by birthweight and social grade.
Children from the best homes tended to improve in performance with increasing age in all birthweight groups. The difference in mean developmental quotient in tests applied at 6 months to 2 years between those of birthweight $2000 \mathrm{~g}$. or less and over $2500 \mathrm{~g}$. was 12 points and also 12 points of IQ at 10-12 years, but on this occasion 6 points higher. The mean scores of children from average working-class homes remained at roughly the same level throughout this age period, with a difference of 10 points between the smallest and largest at birth, both in tests applied in the first two years of life and in the last two years of primary school. In children from the poorest homes the trend was downwards in all birthweight groups but there was little deterioration in performance in those who were smallest at birth; thus, at secondary school age the difference in performance by birthweight was reduced in this social group. It is tempting to hypothesize that this may be explained by the interest taken in these very low birthweight children in the preschool period, in particular the local health visitor was in frequent attendance encouraging the mother to regard the baby as someone who required special care. It was certainly my own impression that these children seemed to receive more attention and stimulation in their first 5 years than did larger born children from similar poor homes.

\section{Behaviour in School}

An assessment of behaviour, using the Bristol Social Adjustment Guides, was made by class teachers in the second year in school for all survey children attending local authority primary schools. This scale is described elsewhere (Drillien, 1964).

This assessment of behaviour in school showed that mean adverse score and the proportion of children considered unsettled (score 10-19) or maladjusted (score 20 and over) increased with decreasing birthweight, more particularly in those who were $2000 \mathrm{~g}$. or less at birth. Boys of all birthweights showed more disturbed behaviour than girls of like birthweight. Disturbed behaviour in all birthweight groups increased with declining social status.

A second assessment of behaviour in school was made at age 11 years for 420 children attending local authority primary schools and 12 children attending special schools for the educationally subnormal and physically handicapped. Table XIII gives the results of this second assessment. Boys who were $2000 \mathrm{~g}$. or less at birth and reared in superior and average homes still showed more disturbed behaviour in school than did those who 
TABLE XIII

Behaviour Assessments (mean score and proportions considered stable, unsettled, and maladjusted) by Birthweight, Sex, and Social Grade

\begin{tabular}{|c|c|c|c|c|c|c|c|c|c|c|c|c|c|}
\hline & & \multicolumn{6}{|c|}{ Male } & \multicolumn{6}{|c|}{ Female } \\
\hline \multicolumn{2}{|c|}{ Social grade } & \multicolumn{2}{|c|}{1 and 2} & \multicolumn{2}{|c|}{3} & \multicolumn{2}{|c|}{4} & \multicolumn{2}{|c|}{1 and 2} & \multicolumn{2}{|c|}{3} & \multicolumn{2}{|c|}{4} \\
\hline Birthweight & SA Score & No. & $\%$ & No. & $\%$ & No. & $\%$ & No. & $\%$ & No. & $\%$ & No. & $\%$ \\
\hline \multirow[t]{3}{*}{-2000} & $\begin{array}{c}0-9 \\
10-19 \\
20 \text { and over }\end{array}$ & $\begin{array}{l}8 \\
6 \\
3\end{array}$ & $\begin{array}{l}47 \\
35 \\
18\end{array}$ & $\begin{array}{l}5 \\
5 \\
8\end{array}$ & $\begin{array}{l}28 \\
28 \\
44\end{array}$ & $\begin{array}{l}6 \\
6 \\
6\end{array}$ & $\begin{array}{l}33 \\
33 \\
33\end{array}$ & $\begin{array}{r}21 \\
4 \\
-\end{array}$ & $\begin{array}{l}84 \\
16 \\
-\end{array}$ & $\begin{array}{r}12 \\
2 \\
4\end{array}$ & $\begin{array}{l}67 \\
11 \\
22\end{array}$ & $\begin{array}{l}4 \\
4 \\
2\end{array}$ & $\begin{array}{l}40 \\
40 \\
20\end{array}$ \\
\hline & Total & 17 & 100 & 18 & 100 & 18 & 100 & 25 & 100 & 18 & 100 & 10 & 100 \\
\hline & Mean & & 11 & & 18 & & 15 & & 6 & & 10 & & 11 \\
\hline \multirow[t]{3}{*}{$2001-2500$} & $\begin{array}{c}0-9 \\
10-19 \\
20 \text { and over }\end{array}$ & $\begin{array}{r}20 \\
6 \\
-\end{array}$ & $\begin{array}{l}77 \\
23 \\
-\end{array}$ & $\begin{array}{r}26 \\
9 \\
6\end{array}$ & $\begin{array}{l}63 \\
22 \\
15\end{array}$ & $\begin{array}{l}5 \\
4 \\
4\end{array}$ & $\begin{array}{l}38 \\
31 \\
31\end{array}$ & $\begin{array}{r}31 \\
4 \\
-\end{array}$ & $\begin{array}{l}89 \\
11 \\
-\end{array}$ & $\begin{array}{r}27 \\
11 \\
2\end{array}$ & $\begin{array}{r}68 \\
28 \\
5\end{array}$ & $\begin{array}{r}3 \\
12 \\
2\end{array}$ & $\begin{array}{l}18 \\
71 \\
12\end{array}$ \\
\hline & Total & 26 & 100 & 41 & 100 & 13 & 100 & 35 & 100 & 40 & 100 & 17 & 100 \\
\hline & Mean & & 5 & & 9 & & 15 & & 3 & & 7 & & 14 \\
\hline \multirow[t]{3}{*}{$2501-$} & $\begin{array}{c}0-9 \\
10-19 \\
20 \text { and over }\end{array}$ & $\begin{array}{r}26 \\
5 \\
4\end{array}$ & $\begin{array}{l}74 \\
14 \\
11\end{array}$ & $\begin{array}{r}13 \\
7 \\
4\end{array}$ & $\begin{array}{l}54 \\
29 \\
17\end{array}$ & $\begin{array}{l}5 \\
5 \\
4\end{array}$ & $\begin{array}{l}36 \\
36 \\
29\end{array}$ & $\begin{array}{r}30 \\
6 \\
-\end{array}$ & $\begin{array}{l}83 \\
17 \\
-\end{array}$ & $\begin{array}{r}25 \\
4 \\
1\end{array}$ & $\begin{array}{r}83 \\
13 \\
3\end{array}$ & $\begin{array}{r}8 \\
7 \\
-\end{array}$ & $\begin{array}{l}53 \\
47 \\
-\end{array}$ \\
\hline & Total & 35 & 100 & 24 & 100 & 14 & 100 & 36 & 100 & 30 & 100 & 15 & 100 \\
\hline & Mean & & 7 & & 9 & & 18 & & 4 & & 5 & & 9 \\
\hline
\end{tabular}

had been above this weight at birth. Boys reared in the poorest homes showed no difference in behaviour disturbance by birthweight, though a difference was noted at 6-7 years. This was not due to an improvement in the behaviour of those of low birthweight but rather to a deterioration in behaviour among those who were over $2000 \mathrm{~g}$. at birth.

Among girls reared in the best homes there was very little difference in behaviour by birthweight at 11 years, though a difference had been evident at 6-7 years. Disturbed behaviour in low weight girls from superior homes had decreased by the age of 11 . Girls reared in average or poor homes still showed an increase in disturbed behaviour with decreasing birthweight.

As at 6-7 years, in all birthweight and social grade groups, boys showed more disturbed behaviour than girls, and in all birthweight and sex groups disturbed behaviour increased with declining social status.

\section{Discussion}

Previous reports from this study of development of low birthweight children have been criticized, with some justification, because all examinations were carried out by one examiner who knew what were the differences in birthweight (e.g. Abramowicz and Kass, 1966). The data presented here were assembled independently by those responsible for ascertaining educational potential, and were not influenced by knowledge of earlier findings.

This analysis confirms the preschool findings. The incidence of moderate or severe handicaps increases with decreasing birthweight, particularly at weights of $2000 \mathrm{~g}$. and under. Even when children with moderate or severe mental, neurological, and physical defects are excluded, children of low birthweight attending normal school are still seen to be at a disadvantage as compared with their larger born contemporaries. This is not due to socio-economic factors, being equally evident when comparing children of different birthweight reared in the best homes with those reared in the worst. Low birthweight boys from all types of home suffer more impairment than low birthweight girls. There is no evidence that low birthweight children 'catch up' as they become older.

These findings agree with those reported from a Baltimore study of 500 low birthweight children and an equal number of normal weight-matched controls who were followed from 40 weeks of age to $12-13$ years. Over $80 \%$ of this group were 
tested at age 8-10 years on a variety of psychological measures (Wiener et al., 1968). Low birthweight children were found to be impaired on a wide variety of psychological measures, and this was not due to differences in social class, maternal attitudes, or practices. The degree of impairment was greatest for children with the lowest birthweight. When the intelligence test data for children 8-10 years old were compared with the data obtained at 6-7 years of age there was no evidence that "catching up' had occurred. A further report about this group studied their scholastic achievement at age 12-13 years (Wiener, 1968). Low birthweight children were found to be impaired on tests of reading and arithmetic achievement. School grade placement was below age expectation. Again, it was stated that these impairments were not due to variations in race or socio-economic status.

In Britain a national sample of 675 low birthweight infants with an equal number of normal weight-matched controls was followed through into secondary school (Douglas, 1960). At 11 years, only $10 \%$ of low weight children who attended normal school gained entry to grammar school compared with $22 \%$ of control children. Douglas considered that this discrepancy was due mainly to differences in the environment of the two groups, which had hitherto been disregarded.

Lubchenco and her colleagues (Lubchenco et al., 1963) re-examined after 10 years $67 \%$ of 94 infants with birthweights $1500 \mathrm{~g}$. or less discharged alive from the Premature Infant Center, Colorado General Hospital, and reported that $68 \%$ of the children were handicapped to some degree, though one-half of these were not seriously crippled. The incidence and severity of handicap was inversely related to birthweight. Over one-half of the children considered intellectually normal (with IQ scores of 90 or over) had experienced educational difficulties and/or emotional disturbances.

McDonald (1967) investigated at 6-9 years more than 1000 children with birthweights of $1800 \mathrm{~g}$. or less, who were originally enrolled in a Medical Research Council study of oxygen therapy and retrolental fibroplasia. After the exclusion of children with neurological and sensory defects and all with IQ scores of less than 50 , no difference was found between mean IQ (on the T.M.L. test) of children of $1360 \mathrm{~g}$. and over and what would be expected in a general population. Lower scores were found in children who had weighed less than 1360 g., but the number in this group was small. McDonald's findings do not agree with those of most other workers in this field.

\section{Summary}

The school disposal and performance of children of different birthweight born 1953-60 is discussed.

The incidence of moderate or severe mental, neurological, or physical handicap increased steadily with decreasing birthweight from $1 \%$ of normal birthweight controls, to $64 \%$ of those who were $1250 \mathrm{~g}$. or less at birth.

Of 596 children born 1953-55 nearly 80\% were retained in the survey until secondary school transfer at age 11-13 years. Low birthweight children were less likely to be selected for courses requiring a higher level of academic competence than were heavier children from similar types of home. Mean IQ score on tests applied at the transfer examination fell with decreasing birthweight in all social groups. A difference in IQ score by birthweight was still evident when all with moderate or severe handicaps were excluded. Low birthweight boys had a higher incidence of handicap and of impairment in normal school than did low birthweight girls. Differences in disturbed behaviour by birthweight were less marked at 11-12 years than at 6-7 years.

I am indebted to the Directors of Education for Edinburgh, Ayrshire, Banffshire, Berwickshire, East Lothian, Fife, Glasgow, Invernessshire, Lanarkshire, Midlothian and Peeblesshire, Ross and Cromarty, Roxburghshire, Selkirkshire, and West Lothian; to head teachers and class teachers in 166 local authority primary schools throughout Scotland; to Miss A. T. Paterson, formerly Principal Educational Psychologist, Edinburgh, and to her successor, Mr. P. H. Priestley, and particularly to my secretary, Mrs. E. Greenan, who has been responsible for the collection of much of the data presented here.

\section{REFERENCES}

Abramowicz, M., and Kass, E. H. (1966). Pathogenesis and prognosis of prematurity. New Engl. F. Med., 275, 878, 938, 1001 , and 1053.

Douglas, J. W. B. (1960). 'Premature' children at primary schools. Brit. med. $\mathcal{F}$, 1, 1008.

Drillien, C. M. (1964). The Growth and Development of the Prematurely Born Infant. Livingstone, Edinburgh.

Lubchenco, L. O., Horner, F. A., Reed, L. H., Hix, I. E., Jr., Metcalf, D., Cohig, R., Elliott, H. C., and Bourg, M. (1963). Sequelae of premature birth. Evaluation of premature infants of low birth weights at ten years of age. Amer. F. Dis. Child., $106,101$.

McDonald, A. (1967), Children of Very Low Birth Weight. M.E.I.U. Research Monograph No. 1. Spastics Society and Heinemann, London.

Tanner, J. M. (1962). Growth at Adolescence, 2nd ed. Blackwell, Oxford.

Wiener, G. (1968). Scholastic achievement at ages 12-13 of prematurely born infants. F. spec. Educ., 2, 237.

_-, Rider, R. V., Oppel, W. C., and Harper, P. A. (1968). Correlates of low birth weight. Psychological status at 8-10 years of age. Pediat. Res., 2, 110.

Correspondence to Dr. C. M. Drillien, Department of Child Life and Health, University of Edinburgh, 17 Hatton Place, Edinburgh 9. 